\title{
Pola Komunikasi Melalui Media Whatsapp Sebagai Sumber Informasi Karyawan Bagian Operasional Di Pt. Artisan Wahyu
}

\author{
Helen Olivia ${ }^{1}$, Trys Setyawan ${ }^{2}$ \\ Universitas Satya Negara Indonesia, helenolivia.fisip@gmail.com \\ Universitas Satya Negara Indonesia, ryssetyawan @gmail.com
}

\begin{abstract}
Abstrak
Abstrak - Penelitian ini membahas tentang bagaimana pola komunikasi dan cara menerima dan menolak pesan yang diterima oleh karyawan PT Artisan Wahyu melalui media Whatsapp. Tujuan dari penelitian ini adalah untuk mengetahui pola komunikasi dan cara penerimaan dan penolakan yang diterima oleh karyawan PT Artisan Wahyu melalui media Whatsapp. Penelitian ini menggunakan teori komunikasi otoritas. Paradigma yang digunakan adalah konstruktivisme dengan pendekatan penelitian kualitatif. Metode yang digunakan adalah studi kasus. Subjek penelitian dalam penelitian ini terdiri dari informan kunci dan informan. Teknik pengumpulan data menggunakan wawancara dan observasi. Hasil penelitian ini menunjukkan bahwa pola komunikasi formal berupa komunikasi top down. Karyawan selalu mengikuti dan mengerjakan arahan yang diberikan oleh pimpinan, karena mereka percaya bahwa pesan yang disampaikan tidak bertentangan dengan tujuan organisasi (untuk kepentingan perusahaan).
\end{abstract}

Kata Kunci: Pola Komunikasi, Karyawan, media Whatsapp

\begin{abstract}
This study discusses how communication patterns and how to accept and reject messages received by PT Artisan Wahyu employees via Whatsapp media. The aim of this research is to know the communication patterns and ways of acceptance and rejection that are accepted by PT Artisan Wahyu employees through Whatsapp media. This study uses the theory of authority communication. The paradigm used is constructivism with a qualitative research approach. The method used is a case study. Research subjects in the study consisted of key informants and informants. Data collection techniques using interviews and observations. The results of this study indicate that the communication pattern is formal in the form of top-down communication. Employees always follow and work on directions given by the leadership, because they believe that the message does not conflict with organizational goals (for the benefit of the company).
\end{abstract}

Keywords: Communication Patterns, Employees, Whatsapp media

SSN: 2355-0287, E-ISSN: 2549-3299

http://ejournal.bsi.ac.id/ejurnal/index.php/jika 


\section{PENDAHULUAN}

Komunikasi memegang peranan penting bagi kehidupan suatu perusahaan baik swasta maupun negeri. Komunikasi sangat penting untuk menjalin hubungan kerjasama antara manusia yang terlibat dalam suatu perusahaan dan mempunyai pengaruh yang sangat besar dalam proses pencapaian tujuan perusahaan tersebut. Komunikasi akan memungkinkan setiap karyawan yang berada di perusahaan untuk saling membantu dan mengadakan interaksi.

Komunikasi akan berhasil apabila pengirim pesan dan penerima pesan samasama mencapai pengertian dan kesimpulan yang sama sesuai dengan yang dimaksudkan, tentang apa yang sebenarnya diinformasikan. Untuk itu, sangat diperlukan keterampilan dalam pemakaian bentuk-bentuk komunikasi dalam suatu perusahaan demi kelancaran aktivitasnya.

Semakin berkembangnya teknologi komunikasi informasi melahirkan berbagai sarana komunikasi salah satunya adalah WhatsApp. Beberapa kelebihan yang dimiliki oleh WhatsApp dibandingkan dengan media yang lain menjadi pendukung setiap kegiatan komunikasi yang akan dilakukan. Pada PT. Artisan Wahyu, Gandaria City Mall media WhatsApp Messenger Group merupakan media untuk berkomunikasi sekaligus mendapatkan informasi secara informal dengan para staffnya, sebagai penyampaian informasi, pemberian arahan, pemberian instruksi, penyampaian pendapat, serta pemutus pendapat secara mendadak.

Dalam proses pertukaran informasi pada lingkungan internal PT Artisan
Wahyu, Gandaria City Mall WhatsApp Messanger Group merupakan sebuah struktur sosial yang dibentuk dari simpul simpul (yang umumnya adalah individu atau organisasi) yang diikat dengan suatu atau lebih tipe relasi spesifik seperti nilai, visi, dan ide. Fenomena yang saat ini dimanfaatkan para anggota WhatsApp Messanger Group untuk memberikan informasi atau pesan yang bersifat penting dalam bentuk info-info aktual yang bermanfaat bagi para anggota WhatsApp Messanger Group untuk mengatahui info aktual dan info real time kapanpun.

Dengan adanya perangkat WhatsApp dapat mempermudah melakukan komunikasi, Pada lingkungan internal organisasi memang dibutuhkan bantuan media komunikasi dalam meningkatkan efektivitas komunikasi, dikarenakan memang bagi pihak internal PT Artisan Wahyu media WhatsApp Messanger Group sangat efektif dan memudahkan dalam mengirimkan gambar dan pesan antar karyawan.

Pesan yang disampaikan melalui media WhatsApp memang sangat membantu pekerjaan terutama dalam hal kecepatan pengiriman informasi tanpa harus membuat jadwal bertemu untuk di komunikasikan dan mudah dijadikan sebagai pengingat dikemudian hari melalui cara melihat history chat pada pihak yang bersangkutan dan dengan cara screenshoot pada pesan yang ingin disimpan. Akan tetapi pada media komunikasi WhatsApp ini juga dapat bisa dimanfaatkan seseorang untuk dijadikan sebagai kepentingan pribadi guna untuk mencitrakan diri sendiri.

Rumusan dalam penelitian ini adalah "Bagaimana pola komunikasi dan cara penerimaan serta penolakan pesan 
informasi yang diterima oleh karyawan operasional PT Artisan Wahyu".

Sedangkan tujuan penelitian adalah Untuk mengetahui pola komunikasi serta mengetahui seperti apa penerimaan dan penolakan pesan informasi yang diterima oleh karyawan operasional PT Artisan Wahyu

Dari penjelasan di atas maka teori-teori yang digunakan adalah sebagai berikut:

\section{Teori Komunikasi Kewenangan}

Definisi Bernard mengenai organisasi formal adalah sebagai suatu sistem kegiatan dua orang atau lebih yang dilakukan secara sadar dan terkoordinasikan yang menitik beratkan konsep sistem dan konsep orang. Bernard menyampaikan bahwa eksistensi suatu organisasi (sebagai suatu sistem kerja sama) bergantung pada kemauan manusia untuk berkomunikasi dan kemauan untuk bekerja sama dalam mencapai suatu tujuan yang sama pula. Selanjutnya Bernard dalam Romli, (2014: 33-34) juga merumuskan seperangkat premis yang dikenal sebagai teori penerimaan kewenangan yang mempunyai maksud bahwa kewenangan yang berasal dari tingkat atas organisasi sebenarnya merupakan kewenangan nominal yang mana kewenangan menjadi nyata apabila diterima. Premis-premis tersebut, yaitu :

a. Orang tersebut memahami pesan yang dimaksud

b. Orang tersebut percaya bahwa pesan tersebut tidak bertentangan dengan tujuan organisasi.

c. Orang tersebut percaya, pada saat ia memutuskan untuk bekerjasama bahwa pesan yang dimaksud sesuai dengan minatnya.

d. Orang tersebut memiliki kemampuan fisik dan mental untuk melaksanakan pesan.
Seperangkat premis tersebut menjadi terkenal sebagai teori komunikasi kewenangan, yakni kewenangan yang berasal dari tingkat atas organisasi sebenarnya merupakan kewenangan nominal. Kewenangan menjadi nyata apabila diterima. Namun Barnerd menyebutkan bahwa banyak pesan yang tidak dapat dianalisis, dinilai dan diterima, atau ditolak dengan sengaja. Namun kebanyakan arahan, perintah dan pesan persuasive termasuk kedalam zona acuh tak acuh (zona of indifference) seseorang untuk menggambarkan gagasan tentang suatu zona of difference, bayangkanlah suatu garis - garis horizaontal yang mempunyai skala $0 \%$ sebagai titik pusatnya dan $100 \%$ dikedua ujungnya. Semakin lebar zona tersebut $100 \%$ untuk bekerja sama memperlihatkan zona yang memanjang dengan kedua arahnya menuju skala $100 \%$. Suatu penolakan pesan yang mutlak (arahan, perintah, permohonan) menunjukan suatu zona yang nilainilainya adalah nol.

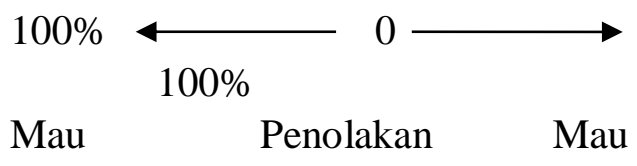

Banyak pesan dalam suatu organisasi dirancang untuk memperlebar zona acuh tak acuh karyawannya. Lebar zona setiap bawahan berbeda antara satu dengan yang lainnya. Seorang bawahan boleh jadi mau menerima suatu pesan dengan penuh kehangatan dan penerimaan, bawahan lainnya tidak mau menerima, tetapi juga tidak berarti menolaknya, sedangkan seorang bawahan ketiga sama sekali menolak pesan tersebut. Lebih lanjut, Bernard 
menyamakan kewenangan dengan komunikasi yang efektif. Penolakan suatu komunikasi sama dengan penolakan kewenangan komunikator. Dengan menerima suatu pesan atau perintah dari orang lain, seseorang memberikan kewenangan kepada perumus pesan dan karenanya menerima kedudukannya sebagai bawahan. Karena inilah Tannenbaum (1950) menyatakan "luas kewenangan yang dimiliki seorang atasan ditentukan oleh luas penerimaan" bawahannya.

Terlepas dari kaitan yang erat antara kewenangan dan komunikasi, Bernard menganggap teknik-teknik komunikasi (tertulis dan lisan) penting untuk mencapai tujuan organisasi, tetapi juga menganggap teknik-teknik tersebut sebagai sumber masalah organisasi. Teknik-teknik komunikasi katanya, menentukan bentuk dan ekonomi internal organisasi. Ketiadaan teknik yang sesuai akan menghilangkan kemungkinan menerima tujuan sebagai suatu dasar organisasi, maka Barnerd lah yang menjadikan komunikasi sebagai suatu bagian yang penting dari teori organisasi dan manajemen. Tampaknya Bernard yakin bahwa komunikasi merupakan kekuataan organisasi (Romli, 2014: 34)

\section{Pola Komunikasi Organisasi}

Secara umum pola kumunikasi (patterns of communication) dibedakan menjadi 2 saluran Purwanto (2006:40-45), yaitu :

1. Saluran Komunikasi Formal

Dalam struktur organisasi, garis, fungsional, maupun matriks, akan tampak berbagai macam posisi atau kedudukan masing-masing sesuai dengan batas tanggung jawab dan wewenangnya. Adapun pola transformasi informasinya dalam kaitannya dengan proses penyampaian informasi dari manajer kepada bawahan, dapat berbentuk 4 pola yaitu : Komunikasi dari atas ke bawah, Komunikasi dari bawah ke atas, Komunikasi Horizontal dan Komunikasi Diagonal

2. Saluran Komunikasi Informal

Dalam jaringan komunikasi informal, semua orang yang ada dalam suatu organisasi, tanpa mempedulikan jenjang hierarki, pangkat, kedudukan atau jabatan, dapat berkomunikasi secara luas. Meskipun hal-hal yang mereka perbincangkan biasanya bersifat umum, seperti mengobrol tentang humor yang baru di dengar, keluarga, anak-anak, dunia olahraga, musik, acara film, dan sinetron tv, dan kadang kala mereka juga membicarakan hal-hal yang berkaitan dengan situasi kerja yang ada dalam organisasinya.

\section{Komunikasi Organisasi}

Pengertian komunikasi organisasi dalam buku "komunikasi organisasi strategi meningkatkan kinerja perusahaan" adalah perilaku perorganisasian yang terjadi dan bagaimana mereka yang terlibat dalam proses itu bertransaksi dan memberi makna atas apa yang sedang terjadi.

\section{Tujuan Komunikasi Organisasi}

Menurut Koontz dalam bukunya Poppy Ruliana, tujuan komunikasi organisasi adalah untuk mengadakan perubahan dan untuk mempengaruhi tindakan ke arah kesejahteraan perusahaan. 


\section{Whatsapp}

Whatsapp adalah aplikasi pesan untuk smartphone dengan basic mirip BlackBerry Messenger. WhatsApp Messenger merupakan aplikasi pesan lintas platform yang memungkinkan kita bertukar pesan tanpa biaya SMS, karena WhatsApp Messenger menggunakan paket data internet yang sama untuk email, browsing web, dan lain-lain. Aplikasi WhatsApp Messenger menggunakan koneksi 3G atau WiFi untuk komunikasi data. Dengan menggunakan WhatsApp, kita dapat melakukan obrolan online, berbagi file, bertukar foto dan lain-lain.

\section{Media Informasi}

Media Informasi secara umum adalah alat untuk mengumpulkan dan menyusun kembali sebuah informasi sehingga menjadi bahan yang bermanfaat bagi penerima informasi. Melalui media informasi masyarakat dapat mengetahui informasi yang ada serta dapat saling berinteraksi satu sama lain.

Pengertian informasi adalah kumpulan data yang diolah menjadi bentuk yang lebih berguna dan lebih bearti bagi yang menerima. Tanpa suatu informasi suatu sistem tidak akan berjalan dengan lancer dan akhirnya bisa mati. Suatu organisasi tanpa adanya suatu informasi maka organisasi tersebut tidak bisa berjalan dan tidak bisa beroperasi (Jogiyanto HM, 2005)

\section{METODOLOGI PENELITIAN}

Paradigma yang digunakan dalam penelitian ini adalah paradigma konstruktivistik. Para peneliti konstruktivistik mempelajari beragam realita yang terkontruksi oleh individu dalam implikasi dari kontruksi tersebut bagi kehidupan mereka dengan yang lain. (Patton, 2002)

Pendekatan Penelitiaan yang digunakan adalah kualitatif kerena untuk mengetahui pola komunikasi dan bagaimana caranya menyikapi pesan atau informasi yang disampaikan oleh pimpinan dan diterima oleh karyawan melalui media komunikasi Whatsapp. Diperlukan tehnik observasi (pengamatan) dan wawancara mendalam (Indepth Interview) yang menurut penulis tehnik wawancara mendalam yang bersifat terbuka serta observasi berupa pengamatan dan mencatat secara sistematis apa yang sedang penulis teliti lebih tepat dipakai untuk memperoleh data yang diperlukan untuk tercapainya kesimpulan dalam penelitian ini.

Metode Penelitian yang digunakan dalam penelitian ini yaitu studi kasus. Dalam penelitian ini digunakan pendekatan studi kasus sebagai bagian dari penelitian kualitatif. untuk menjelaskan bagaimana keberadaan dan mengapa kasus tersebut terjadi. Penelitian studi kasus bukan sekedar menjawab pertanyaan penelitian tentang 'apa' (what) obyek yang diteliti, tetapi lebih menyeluruh dan komprehensif lagi adalah tentang 'bagaimana' (how) dan 'mengapa' (why).

\section{Subyek dan Obyek Penelitian}

Subyek penelitian ini adalah Karyawan Operasional di PT Artisan Wahyu, Gandaria City. Obyek penelitian ini meliputi: PT Artisan Wahyu, Gandaria City Mall. 


\section{Key Informan dan informant}

Key Informan yang telah memenuhi kriteria diatas adalah Molyvia selaku Deputy Operation Manager dari PT Artisan Wahyu. Maka peneliti memilih Zainal Mutaqin selaku Admin Security, Dicky selaku Petugas Pest Control, Heru Wahyu selaku SPV Tenant Relation, Eko Waluyo selaku Customer Service \& Receptionist, Aziz Saputra selaku Staff Engineering, dan Leni Nurmaulidyanti selaku Admin Safety.

\section{Teknik Pengumpulan Data}

\section{Wawancara}

Maksud mengadakan wawancara, seperti ditegaskan oleh Lincoln dan Guba (1985:266) dalam buku Lexy J. Moleong, Metodolagi Penelitian Kualitatif (2017:186), antara lain: mengonstruksi mengenai orang, kejadian, organisasi, perasaan, motivasi, tuntutan, kepedulian, dan lain-lain kebulatan: merekonstruksi kebulatan-kebulatan demikian sebagai yang dialami masa lalu: memproyeksikan kebulatan-kebulatan sebagai yang diharapkan untuk dialami pada masa yang akan datang; memverifikasi, mengubah, dan memperluas informasi yang diperoleh dari orang lain, baik manusia maupun bukan manusia (tringulasi); dan memverfikasi, mengubah dan memperluas konstruksi yang dikembangkan oleh peneliti sebagai pengecekan anggota.

2. Observasi (pengamatan)

Teknik ini digunakan untuk menghimpun keterangan yang dilakukan dengan mengadakan pengamatan dan pencatatan secara sistematis terhadap fenomena yang akan dijadikan objek pengamatan.
Teknik ini dapat mendukung data yang diperoleh melalui kuesioner atau wawancara, sehingga akan diketahui apakah datayang diberikan responden sesuai dengan keadaan yang sebenarnya.

\section{Teknik Analisis Data}

Menurut Miles dan Huberman mengemukakan "bahwa aktivitas dalam analisis data kualitatif dilakukan secara interaktif dan berlangsung secara terus menerus sampai tuntas, sehingga data sudah jenuh. Aktivitas dalam analisis data, yaitu, data display, dan conclusion drawing verification." (Sugiyono, 2009)

\section{Teknik Keabsahan Data}

Dalam penelitian ini penulis menggunakan triangulasi sumber, datadata yang diperoleh oleh penulis dari berbagai sumber di analisis dengan menyusun data secara sistematis dari hasil penelitian antara lain wawancara, catatan lapangan, dan refrensi lainnya dan dibandingkan sehingga data yang dihasilakn akurat dan mudah dicerna untuk diinformasikan kepada khalayak.

\section{HASIL DAN PEMBAHASAN}

Pesan informasi yang disampaikan melalui bantuan media WhatsApp dan diterima oleh Karyawan adalah cukup baik karena pola komunikasi yang ada di perusahaan tersebut adalah Pola komunikasi bersifat formal yakni suatu proses komunikasi yang bersifat resmi dan biasanya dilakukan di dalam lembaga formal melalui garis perintah atau sifatnya instruktif, berdasarkan struktur organisasi oleh pelaku yang berkomunikasi sebagai petugas organisasi dengan status masing- 
masing yang tujuannya menyampaikan pesan yang terkait dengan kepentingan perusahaan. Juga dapat dikatakan formal ketika komunikasi antara dua orang atau lebih yang ada pada suatu organisasi dilakukan berdasarkan prinsip-prinsip dan struktur organisasi.

Komunikasi yang ada pada karyawan operasional PT Artisan Wahyu adalah bentuk komunikasi dari atas kebawah yakni bentuk komunikasi ini adalah komunikasi yang berasal dari pimpinan tertinggi ditunjukkan kepada pimpinan menengah terus mengalir melewati tingkat manajemen untuk kemudian disampaikan kepada bawahan. Di samping mengomunikasikan perintah, komunikasi dari atas kebawah juga meliputi informasi tentang tujuan organisasi, kebijakan, peraturan, insentif, manfaat, hak-hak khusus ataupun umpan balik dari atasan tentang hasil pelaksanaan tugas oleh bawahan.

Data informasi yang didapatkan berupa informasi yang diterima oleh karyawan melalui observasi kepada karyawan PT. Artisan Wahyu melalui media Whatsapp dari salah satu informan adalah sebagai berikut :

a. Informasi Undangan Kegiatan Acara Informasi ini berisikan keterangan waktu, tempat, dan ajakan kepada seluruh department untuk bisa hadir dalam mengikuti acara atau kegiatan tausiah. Dalam hal ini komunikasi yang disampaikan dari atasan kepada bawahan dengan bantuan media whatsapp group kerja dalam bentuk pembicaraan internal organisasi.

b. Informasi Laporan Pekerjaan

Informasi ini berisikan laporan kegiatan pekerjaan yang dilakukan atau pekerjaan yang sudah diselesaikan oleh departemen terkait. Seperti misalnya :

1. Pekerjaan penggalian tanaman bambu, treatment antisipasi hama kecoa di area toilet customer, brushing manual sudutan lantai parkir, pekerjaan ini dilakukan oleh department Housekeeping.

2. Kegiatan patroli di area parkir, laporan traffic area luar dan dalam Gandaria City Mall, pekerjaan ini dilakukan oleh department Security

3. Perbaikan urinoir toilet yang rusak, AC mati, lampu padam, pekerjaan ini dilakukan oleh department Engineering.

4. Pengecatan tembok yang sudah terkelupas, perbaikan lantai yang rusak, dan yang lainnya, pekerjaan ini dilakukan oleh department Building Service.

5. Pengecekan Apar di area toko, panel listrik \& gas, pekerjaan ini dilakukan oleh department Safety.

6. Checking floor area tenant, koordinasi, mengurusi complain tenant, kegiatan ini dilakukan oleh department Tenant Relation.

7. Melayani tamu yang datang, memberikan pelayanan dan sambutan yang baik dan ramah kepada customer, pekerjaan ini dilakukan oleh department Customer Service

c. Informasi Laporan Temuan

Informasi ini bersikan laporan temuan kerusakan \& kehilangan. Seperti misalnya, dustbin sensor rusak atau error, urinoir rusak atau mamper, handryer mati, lampu mati, kran di wastafel tidak keluar air, customer kehilangan tas, dompet, atau yang 
lainnya. Laporan temuan ini bisa dikerjakan oleh semua department.

d. Informasi yang didapatkan dari atasan (intruksi pekerjaan)

Informasi ini berisikan perintah berupa foto atau gambar yang dikirimkan ke media whatsapp untuk di infokan kepada petugas atau karyawan yang bertugas pada saaat itu. Menurut informasi dari salah satu informan mengatakan bahwa beberapa pihak atasan menyampaikan intruksi pekerjaan hanya berupa gambar dan kata perintah saja, pesan tersebut tidak ada detail lokasi, dan penjelasan pekerjaan yang harus dilakukan. Selain itu terdapat pula komunikasi informal yang terjadi antar pihak atasan dengan pihak karyawan atau komunikasi antara orang yang ada dalam suatu organisasi, akan tetapi tidak direncanakan atau tidak ditentukan dalam struktur organisasi. Komunikasi informal yang terjadi pada karyawan operasional di PT Artisan Wahyu, seperti misalnya pihak atasan bertanya melalui chat pribadi di media whatsapp kepada karyawan menanyakan perihal kabar atau keadaannya "Sudah sehat belum?" bila ada karyawan yang sedang sakit. Dan juga menanyakan "Apakah sudah makan ?" bila usai jam makan siang. Atau terkadang juga pihak atasan meminta karyawannya untuk menemani pergi keluar untuk berkeliling area mall. Serta pihak atasan mengingatkan kepada karyawannya untuk menghubunginya bila ada suatu hal yang terjadi saat pihak atasan sedang tidak ada di kantor.
Komunikasi informal jarang terjadi atau tidak sering terjadi dibandingkan dengan komunikasi formal karena pada karyawan operasional yang ada di PT Artisan Wahyu waktu yang dimiliki pada saat bekerja lebih banyak di tempat bekerja (di lapangan), sehingga dalam hal ini pihak atasan lebih sering menanyakan persoalan pekerjaan.

Hasil penelitian menunjukan kualitas penyampaian dan penerimaan komunikasi yang ada di PT Artisan Wahyu sudah cukup baik dilakukan, dan dari hasil yang didapatkan penulis dilapangan media komunikasi WhatsApp untuk membantu pekerjaan sudah tepat karena dengan cara ini tidak lagi menunggu atau bertemu dengan pihak yang kita ingin temui untuk berkomunikasi.

Berdasarkan teori komunikasi kewenangan yang menyatakan bahwa kewenangan berasal dari tingkat atas organisasi yang sebenarnya merupakan kewenangan nominal yang mana kewenangan menjadi nyata apabila diterima. Pihak atasan mempunyai wewenang untuk menyampaikan pesan atau informasi kepada karyawan dan dianggap nyata bila pesan dan informasi tersebut diterima.

Di PT Artisan Wahyu ditemukan juga beberapa karyawan yang mendapat arahan atau instruksi kerja yang tidak sesuai dengan minatnya, dan tidak memiliki kemampuan yang tepat untuk melakukan pekerjaan yang diperintahkan sesuai dengan kemampuannya. Sejauh ini seorang 
bawahan boleh jadi mau menerima suatu pesan dengan penuh kehangatan dan penerimaan, bawahan lainnya tidak mau menerima, tetapi juga tidak berarti menolaknya.

Kemudian ditemukan juga banyak yang melakukan penerimaan pesan dikarenakan mereka percaya bahwa pesan tersebut tidak bertentangan dengan tujuan organisasi dan hal itu dilakukan karena sudah menjadi kewenangan seorang pimpinan memberikan arahan, pesan, atau informasi kepada seorang karyawannya.

\section{KESIMPULAN}

Dari hasil penelitian yang telah dilaksanakan di PT Artisan Wahyu, dapat disimpulkan bahwa :

1. Pihak pimpinan PT Artisan Wahyu lebih percaya pada pesan tertulisan dan bukti foto atau menggunakan alat-alat elektronik dari pada pesan yang disampaikan secara lisan dengan tatap muka, dalam hal ini dapat dilihat dari hasil wawancara pada informan ke 2 (dua) setelah bertemu dengan atasan dan menunjukan bukti pesan berupa chating dengan rekan kerjanya.

2. Karyawan dibebani dengan informasiinformasi pekerjaan seperti laporan briefing, laporan progres dan hasil pekerjaan, laporan temuan kehilangan, kerusakan, pengumuman atau pemberitahuan, dan laporan pekerjaan lainnya, sehingga banyak sekali pesanpesan yang harus di baca dan di check oleh karyawan.

3. Ketepatan waktu pengiriman pesan mempengaruhi komunikasi ke bawah, dimana bila ada suatu peristiwa atau pekerjaan yang bersifat urgent ketepatan waktu pengiriman pesan atau jawaban dari atasan sangatlah penting untuk memperlancar berjalannya proses pekerjaan.

\section{REFERENSI}

Jogiyanto, H.M., 2005, Analisa dan Desain Sistem Informasi: Pendekatan Terstruktur Teori dan Praktik Aplikasi Bisnis, ANDI, Yogyakarta

Moleong, Lexy J. (2017). Metode Penelitian Kualitatif, cetakan ke-36, Bandung : PT. Remaja Rosdakarya Offset

Patton, P. (2002). EQ (Kecerdasan Emosional) di Tempat Kerja. Jakarta: PT Pustaka Delapratasa.

Purwanto, Ngalim. (2006). Psikologi Pendidikan. Bandung: PT Remaja Rosdakarya

Romli, Khomsahrial, 2014, Komunikasi Organisasi, Edisi Revisi, Jakarta : PT Grasindo, hlm 13.

Sugiyono, 2009, Metode Penelitian Kuantitatif, Kualitatif dan R\&D, Bandung : Alfabeta

\section{BIODATA PENULIS}

Helen Olivia, S.Ikom., M.Ikom adalah dosen di Universitas Satya Negara Indonesia. Menyelesaikan jenjang pendidikan Strata Satu (S1) di Universitas Prof. Dr. Moestopo (B) Jakarta Tahun 2007. Fakultas Ilmu Komunikasi Jurusan Ilmu Komunikasi (Humas) dan menyelesaikan Strata Dua (S2) Magister Komunikasi Korporat Tahun 2012. Selain aktif mengajar juga aktif sebagai narasumber PR, moderator, MC untuk kegiatan seminar politik komunikasi, menghandle event dan peneliti komunikasi.

Trys Setyawan, dilahirkan di Jakarta pada tanggal 20 April 1993. Menyelesaikan pendidikan di Sekolah 
Dasar di SD Negeri Rawa Buntu, kemudian melanjutkan Pendidikan di SMP Era Informatika serta Sekolah Menengah Kejuruan Era Informatika Jurusan Teknik Komputer dan Jaringan. Pada tahun 2014 melanjutkan pendidikan di perguruan tinggi swasta, tepatnya di Universitas Satya Negara Indonesia (USNI) Fakultas Ilmu Sosial Dan Ilmu Politik pada Program Studi Hubungan Masyarakat. 